\title{
Genistein reduces the activation of AKT and EGFR, and the production of IL6 in cholangiocarcinoma cells involving estrogen and estrogen receptors
}

\author{
PARIYADA TANJAK ${ }^{1,2}$, APINYA THIANTANAWAT ${ }^{1-3}$, \\ PIYAJIT WATCHARASIT ${ }^{1-3}$ and JUTAMAAD SATAYAVIVAD ${ }^{1-3}$
}

\author{
${ }^{1}$ Laboratory of Pharmacology, Chulabhorn Research Institute; ${ }^{2}$ Applied Biological Sciences Program, \\ Chulabhorn Graduate Institute, Bangkok 10210; ${ }^{3}$ Center of Excellence on Environmental Health and Toxicology, \\ Office of Higher Education Commission, Ministry of Education, Bangkok 10400, Thailand
}

Received May 7, 2017; Accepted March 20, 2018

DOI: 10.3892/ijo.2018.4375

\begin{abstract}
Cholangiocarcinoma (CCA) is a malignant tumor of the biliary epithelium associated with Opisthorchis viverrini, primary sclerosing cholangitis and hepatitis viral infection. In the global population, men have higher incidence rates for CCA than women; thus, a gender disparity in the progression of chronic inflammation of the biliary duct leading to malignancy may involve the effects of estrogen (E2). Genistein (GE), a prominent phytoestrogen found in soy products, is an estrogen receptor $\beta(\operatorname{ER} \beta)$ agonist and a tyrosine kinase inhibitor. The present study investigated the effects of GE on the growth of CCA cells by cell viability assay. The effects on signaling proteins were detected by western blot analysis and ELISA. Gene expression was examined by RT-qPCR. Two human intrahepatic CCA cell lines, HuCCA-1 and RMCCA-1, were utilized. GE (50-200 $\mu \mathrm{M})$ reduced the viability of the two cell lines, and also inhibited the activation of epidermal growth factor receptor (EGFR) and AKT, as evidenced by decreasing protein levels of phosphorylated (p)-EGFR (Tyr1173) and p-AKT (Ser473), respectively. GE altered the mitogen-activated protein kinase signaling cascade by mediating decreased protein levels of p-p38 and increased protein levels of p-ERK1/2. GE significantly decreased the levels of interleukin 6 (IL6) and induced the expression of inducible nitric oxide synthase (iNOS). GE also downregulated the expression of $\mathrm{p}-\mathrm{ER} \alpha$ (Ser118) protein and ER $\alpha$ mRNA levels. Finally, GE induced the downregulation of the protein levels of ER $\beta$. Of note, E2 deprivation potentiated the GE-induced reduction of p-EGFR (Tyr1173) and total AKT proteins and production of IL6, and mediated the downregula-
\end{abstract}

Correspondence to: $\operatorname{Dr}$ Apinya Thiantanawat, Laboratory of Pharmacology, Chulabhorn Research Institute, 54 Kamphaeng Phet 6, Talat Bang Khen, Laksi, Bangkok 10210, Thailand

E-mail: apinya@cri.or.th

Key words: genistein, cholangiocarcinoma, estrogen receptor, epidermal growth factor receptor, AKT, interleukin 6 tion of GE-induced iNOS protein. In conclusion, GE inhibited the growth of human CCA cell lines by reducing the activation of EGFR and AKT, and by attenuating the production of IL6. E2 and ER were also involved in the growth-inhibitory effect of GE in CCA cells.

\section{Introduction}

Cholangiocarcinoma (CCA) is one of the leading types of cancer in Thailand, with patients having a poor prognosis and treatment outcome. As there is no effective chemotherapeutic treatment at present, additional therapeutic approaches with specific and effective targets are required for CCA treatment. In Thailand, the incidence rate of CCA is associated with the prevalence of Opisthorchis viverrini infection (1). Chronic inflammation, often coupled with injury of the bile duct epithelium, is a common and important contributor to the malignant transformation of cholangiocytes. Nitric oxide, activated by inflammatory cytokines, is implicated in inflammation and the carcinogenesis of CCA (2). Interleukin 6 (IL6) is among the inflammatory cytokines that have been associated with the pathogenesis of CCA. The levels of IL6 have been observed to be elevated in patients with CCA, compared with those in healthy controls (3). Through the AKT signaling pathway, IL6 upregulates myeloid leukemia 1, resulting in resistance to apoptosis in CCA (4). The involvement of other signaling molecules has also been investigated in CCA cell growth and survival.

Several studies have reported the involvement of phosphatidylinositol-3 kinase (PI3K)/AKT/mammalian target of rapamycin (mTOR) signaling in CCA. It has been shown that the expression and activation of $\mathrm{AKT}$ protein increase during the development and progression of CCA $(5,6)$, and that AKT is a promising target for CCA treatment (7). In addition, an activated PI3K/AKT signaling pathway is frequently found in CCA cells resistant to chemotherapy (8).

Epidemiological investigations have revealed gender disparities in CCA, for example, the incidence rate is higher in men (9). Liver biopsies from patients with intrahepatic CCA are positive for the estrogen receptor (ER), both ER $\alpha$ and ER $\beta$ subtypes, whereas normal liver cholangiocytes are ER-negative (10). The 
growth-stimulating effects of estrogen (E2) via ER signaling or crosstalk with the epidermal growth factor receptor (EGFR) and AKT pathways are well established in breast cancer and endometrial cancer (11-14). E2 has also been shown to be involved in the proliferation $(10,15)$ and invasion (16) of CCA. Additionally, E2 stimulates the production of IL6 in biliary epithelial cells (17). These observations suggest that the disruption of E2 may be useful for CCA therapy.

Genistein (GE), an isoflavone found in soybeans, has multi-targeted biological effects in cancer cells, leading to the inhibition of cell growth and induction of apoptotic cell death in several cancer cell lines, including breast (18), lung (19) and colon cancer (20). In addition to being a phytoestrogen, the biological effects of GE have been reported to be associated with tyrosine kinase inhibition, anti-inflammatory effects $(21,22)$ and the inhibition of AKT $(23,24)$.

The present study investigated the effects of GE and the involvement of $\mathrm{E} 2$ in human CCA cell lines by targeting AKT, EGFR receptor tyrosine kinase, IL6, and ER. The results showed that GE exhibited cytotoxicity in human HuCCA-1 and RMCCA-1 cell lines. GE reduced the protein levels of p-AKT and p-EGFR, and the production of IL6. Additionally, GE induced downregulation of the expression of ER $\alpha$ at the mRNA and protein levels. The present study demonstrated for the first time, to the best of our knowledge, that E2 deprivation potentiated the GE-induced reduction in the production of IL6, and protein levels of total AKT, p-AKT (Ser473) and p-EGFR (Tyr1173) in CCA.

\section{Materials and methods}

Chemicals and reagents. GE, 17- $\beta$ estradiol (E2) and triciribine were purchased from Sigma-Aldrich; EMD Millipore (Billerica, MA, USA). LY294002 was obtained from Cayman Chemical Company (Ann Arbor, MI, USA). AG1478 was acquired from Merck Millipore (Darmstadt, Germany). Ham's F12 medium, phenol red-free RPMI-1640 medium, and supplements were purchased from Gibco; Thermo Fisher Scientific,Inc. (Waltham, MA, USA). Fetal bovine serum (FBS) treated with dextrancharcoal (CSS) was purchased from HyClone; GE Healthcare Life Sciences (Logan, UT, USA). Antibodies were obtained as follows: Anti-human p-AKT (Ser473) cat. no. 13038, AKT cat. no. 9272, p-p38 (Thr180/Tyr182) cat. no. 9215, p38 cat. no. 9217, p-ERK1/2 (Thr202/Tyr204) cat. no. 9106 and ERK1/2 cat. no. 9102 from Cell Signaling Technology, Inc. (Danvers, MA, USA); ER $\alpha$ cat. no. sc-8002, p-ER $\alpha$ (Ser118) cat. no. sc-12915, p-EGFR (Tyr1173) cat. no. sc-12351 and EGFR cat. no. sc-03 from Santa Cruz Biotechnology, Inc. (Santa Cruz, CA, USA); ER $\beta$ cat. no. 05-824 and inducible nitric oxide synthase (iNOS) cat. no. ABN26 from Merck Millipore, and $\beta$-actin cat. no. A5316 from Sigma-Aldrich; EMD Millipore (Billerica, MA, USA). HRP-conjugated secondary antibodies obtained were as follows: Anti-rabbit IgG (cat. no. 5127) from Cell Signaling Technology, Inc.; anti-goat IgG (cat. no. HAF109) from R\&D System Inc. (Minneapolis, MN, USA); and anti-mouse IgG (cat. no. 1706516) from Bio-Rad Laboratories, Inc. (Hercules, CA, USA).

Cell lines and cell culture. The HuCCA-1 and RMCCA-1 human intrahepatic CCA cell lines were established and kindly provided by Professor Stitaya Sirisinha and Dr Kawin Leelawat, respectively $(25,26)$. The cells were cultured in complete medium (FBS condition) containing Ham's F12 culture medium supplemented with $10 \%$ FBS, 2 mM L-glutamine, $100 \mathrm{U} / \mathrm{ml}$ penicillin and $100 \mu \mathrm{g} / \mathrm{ml}$ streptomycin. For the E2-deprived condition (CSS condition), cells were switched to a culture of phenol redfree RPMI-1640 medium supplemented with 10\% CSS, $2 \mathrm{mM}$ L-glutamine, $100 \mathrm{U} / \mathrm{ml}$ penicillin and $100 \mu \mathrm{g} / \mathrm{ml}$ streptomycin for $24 \mathrm{~h}$ prior to treatment. The cells were maintained at $37^{\circ} \mathrm{C}$ in a humidified atmosphere of $5 \% \mathrm{CO}_{2}$.

The difference between the FBS and CSS cultures was the concentration of steroid hormone E2. The E2 concentration in FBS is reported to be $>100 \mathrm{pg} / \mathrm{ml}$ (27), whereas the concentration in CSS is in the range of $15-20 \mathrm{pg} / \mathrm{ml}$ (from COA of product). This model has been commonly used by others and by our group at the Laboratory of Pharmacology, Chulabhorn Research Institute (Bangkok, Thailand) as in vitro E2-deprived cell culture condition $(28,29)$.

Cell viability assay. The cells maintained in the FBS condition were plated into 96 -well plates at $1 \times 10^{4}$ cells/well. Following incubation for $24 \mathrm{~h}$, the medium containing various concentrations of GE $(50-200 \mu \mathrm{M})$ or vehicle $(0.1 \%$ DMSO) were added in triplicate wells and incubated at $37^{\circ} \mathrm{C}$ for 24 or $48 \mathrm{~h}$. Following the manufacturer's protocol, following this period of incubation, $10 \mu \mathrm{l}$ of PrestoBlue ${ }^{\mathrm{TM}}$ cell viability reagent (Invitrogen; Thermo Fisher Scientific, Inc.) was used to detect cell viability. The reaction was measured by spectrofluorometry to detect fluorescence at $560 \mathrm{~nm}$ for excitation and $590 \mathrm{~nm}$ for emission using a SpectraMax microplate reader (Molecular Devices LLC, Sunnyvale, CA, USA).

Western blot analysis. The HuCCA-1 or RMCCA-1 cells were plated on a $100-\mathrm{mm}$ culture dish at $4 \times 10^{6}$ cells with $10 \mathrm{ml}$ per plate and treated with GE $(50,100$ and $200 \mu \mathrm{M}$ for $0.5,6$ or $24 \mathrm{~h})$, LY294002 (20 $\mu \mathrm{M}$ for $0.5,6$ or $24 \mathrm{~h})$, triciribine $(20 \mu \mathrm{M}$ for 0.5 , 6 or $24 \mathrm{~h})$, or AG1478 $(0.01 \mu \mathrm{M}$ for $6 \mathrm{~h})$ in either FBS or CSS conditions, according to each experimental design. Following the exposure period, the cells were collected and centrifuged $500 \mathrm{x} \mathrm{g}$ for $10 \mathrm{~min}$ at $4^{\circ} \mathrm{C}$. The pellets were then re-suspended in RIPA buffer containing $50 \mathrm{mM}$ Tris (pH 7.4), $150 \mathrm{mM}$ $\mathrm{NaCl}, 1 \mathrm{mM}$ EDTA, $0.1 \%$ SDS, $1 \%$ sodium deoxycholate, $1 \%$ NP40 and protease inhibitors (Calbiochem; EMD Millipore) mixed with $100 \mathrm{mM}$ PMSF and phosphatase inhibitors $(1 \mathrm{mM}$ $\mathrm{Na}_{3} \mathrm{VO}_{4}, 100 \mathrm{mM} \mathrm{NaF}$ and $1 \mathrm{nM}$ okadaic acid). The protein concentration was determined using Bradford reagent according to the manufacturer's protocol (Bio-Rad Laboratories, Inc.). For immunoblotting, $50 \mu \mathrm{g}$ of total protein was separated using 7.5\% SDS-PAGE and then electro-transferred onto a nitrocellulose membrane (Amersham Biosciences, Buckinghamshire, UK). The membrane was incubated in blocking buffer [5\% non-fat dry milk in TBST buffer $(10 \mathrm{mM}$ Tris- $\mathrm{HCl} \mathrm{pH} 8.0$, $150 \mathrm{mM} \mathrm{NaCl}$, and $0.05 \%$ Tween-20)] for $1 \mathrm{~h}$ at room temperature. The membrane was probed overnight with primary antibody p-AKT (Ser473) $(1: 1,000)$, AKT $(1: 2,000)$, p-p38 (Thr180/Tyr182) (1:2,000), p38 (1:2,000), p-ERK1/2 (Thr202/ Tyr204) (1:2,000), ERK1/2 (1:2,000), ER $\alpha$ (1:1,000), p-ER $\alpha$ (Ser118) (1:1,000), p-EGFR (Tyr1173) (1:1,000), EGFR $(1: 1,000)$, $\operatorname{ER} \beta(1: 2,000)$ or iNOS $(1: 1,000)$ at $4^{\circ} \mathrm{C}$, followed by incubation with appropriate HRP-conjugated secondary antibody $(1: 3,000)$ 
Table I. Primers pairs for reverse transcription-quantitative polymerase chain reaction analysis.

\begin{tabular}{|c|c|c|c|}
\hline Gene & Primer sequence & Product size (bp) & Accession no. \\
\hline$E R \alpha$ forward & 5'-CGTGGTGCCCCTCTATGA-3' & 165 & NM_000125.3 \\
\hline$E R \alpha$ reverse & 5'-TCCCCCGTGATGTAATAC-3' & & \\
\hline$E R \beta 1$ forward & 5'-GAATGCCCACGTGCTTCGCG-3' & 150 & NM_001271877.1 \\
\hline$E R \beta 1$ reverse & 5'-GCCTGTGACCTCTGTGGGCC-3' & & \\
\hline$E R \beta 2$ forward & 5'-ACССТСТАAATCAACTCGGTGGCCT-3' & 240 & NM_001291723.1 \\
\hline$E R \beta 2$ reverse & 5'-CCCTGGGCAGTTAAGGAGACCT-3' & & \\
\hline$G A P D H$ forward & 5'-GAAGGTGAAGGTCGGAGTC-3' & 226 & NM_002046.5 \\
\hline$G A P D H$ reward & 5'-GAAGATGGTGATGGGATTTC-3' & & \\
\hline
\end{tabular}

$E R$, estrogen receptor; GAPDH, glyceraldehyde-3-phosphate dehydrogenase.

at room temperature for $2 \mathrm{~h}$. Subsequently, the blot was reacted with a chemiluminescent substrate (Amersham; GE Healthcare Life Sciences, Chalfont, UK), and exposed to X-ray film (GE Healthcare Life Sciences). The protein levels were quantified by densitometry using ImageQuant TL 7.0 software (GE Healthcare Life Sciences). The expression level of each protein was normalized to the corresponding protein level of $\beta$-actin derived from the same blot.

Enzyme-link immunosorbentassay(ELISA). The culture medium collected following treatment was analyzed for levels of IL6 using the DuoSet ELISA Development kit (R\&D System Inc.). The absorbance was immediately measured at $450 \mathrm{~nm}$, with the wavelength correction at $570 \mathrm{~nm}$, on a SpectraMax microplate reader (Molecular Devices LLC., San Jose, CA, USA).

Reverse transcription-quantitative polymerase chain reaction (RT-qPCR) analysis. Total mRNA was isolated from $4 \times 10^{6}$ HuCCA-1 cells using an RNA purification cell kit (5 PRIME GmbH, Hamburg, Germany) according to the manufacturer's recommendations. Contaminating DNA was removed using the Turbo DNA-free ${ }^{\mathrm{TM}}$ DNase kit (Applied Biosystems; Thermo Fisher Scientific, Inc.). A master mixture was created in a $50 \mu \mathrm{l}$ total reaction volume containing $1 \mathrm{X} R N A$-direct ${ }^{\mathrm{TM}}$ SYBR $^{\circledR}$-Green Realtime PCR Master Mix (Toyobo Co., Ltd., Osaka, Japan), $0.2 \mu \mathrm{M}$ forward primer, $0.2 \mu \mathrm{M}$ reverse primer and $250 \mathrm{ng} / \mu \mathrm{l}$ RNA sample. The RT-qPCR analysis was performed on an ABI-StepOnePlus thermocycler (Applied Biosystems; Thermo Fisher Scientific, Inc.), starting with the RT reaction $\left(10 \mathrm{~min}\right.$ at $\left.50^{\circ} \mathrm{C}\right)$, followed by 40 cycles of two-step PCR $\left(95^{\circ} \mathrm{C}\right.$ for $10 \mathrm{sec}$ and $60^{\circ} \mathrm{C}$ for $\left.30 \mathrm{sec}\right)$. Standard melting curve analysis was performed. The housekeeping gene, glyceraldehyde-3-phosphate dehydrogenase, was used for normalization. The relative quantification of the target genes was performed using StepOnePlus ${ }^{\mathrm{TM}}$ software version 2.1 (Applied Biosystems; Thermo Fisher Scientific, Inc.), based on the $2^{-\Delta \Delta C q}$ method, and resulted in the relative transcription level of the target genes in treated cells, compared with those in control cells. The primer sequences are listed in Table I.

Statistical analysis. Data are expressed as the mean \pm standard error of the mean calculated from at least three independent
A

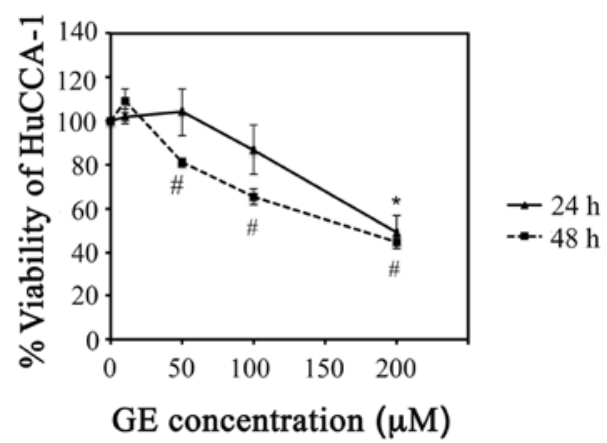

B

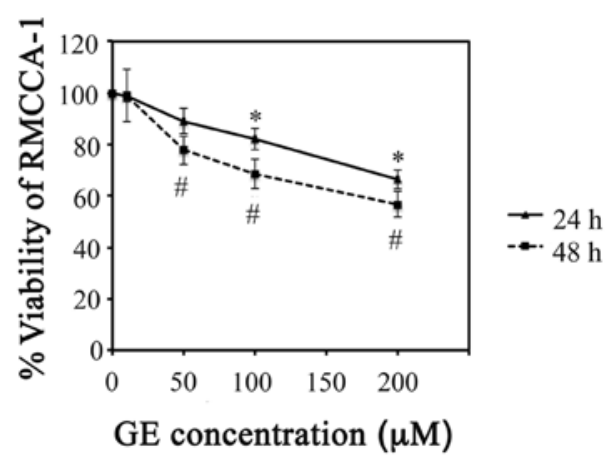

Figure 1. GE reduces HuCCA-1 and RMCCA-1 cell viability. (A) HuCCA-1 and (B) RMCCA-1 cells cultured in complete medium were treated with 10 , 50, 100 and $200 \mu \mathrm{M}$ GE for 24 and $48 \mathrm{~h}$. GE $(0 \mu \mathrm{M})$ represents $0.1 \%$ DMSO vehicle control. Data are presented as the mean \pm standard error of the mean of four independent experiments. ${ }^{*} \mathrm{P}<0.05$, vs. $0 \mu \mathrm{M}$ GE at $24 \mathrm{~h}$ post-treatment; ${ }^{*} \mathrm{P}<0.05$, vs. $0 \mu \mathrm{M}$ GE at $48 \mathrm{~h}$ post-treatment. GE, genistein.

experiments. Multiple comparisons were performed using one-way analysis of variance with Dunett's multiple comparisons test by Stata ${ }^{\mathrm{TM}}$ program version 10.1 (StataCorp, College Station, TX, USA). $\mathrm{P}<0.05$ was considered to indicate a statistically significant difference.

\section{Results}

GE reduces $H u C C A-1$ and $R M C C A-1$ cell viability. Two human CCA cell lines, HuCCA-1 and RMCCA-1, were used to investigate the cytotoxic effect of GE. As shown in Fig. 1, 
A

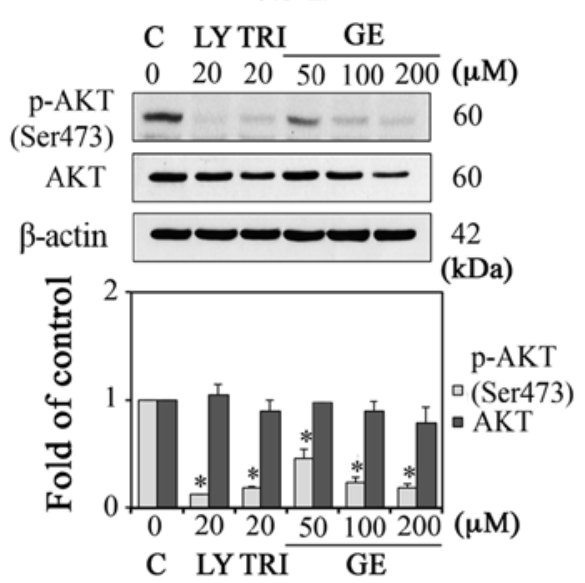

$\mathrm{D}$

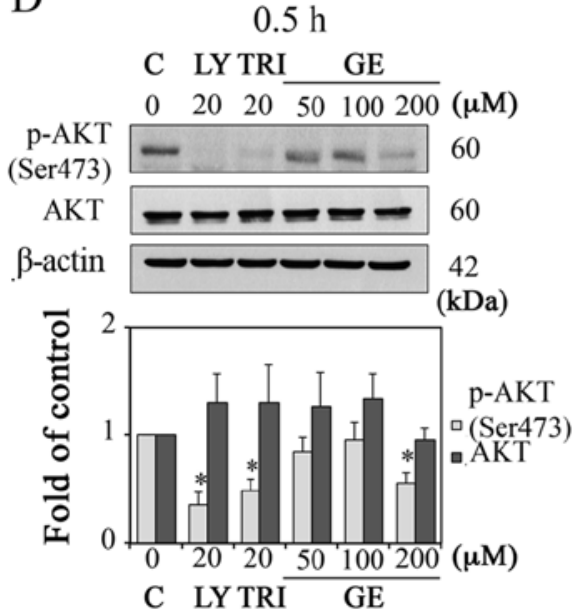

B

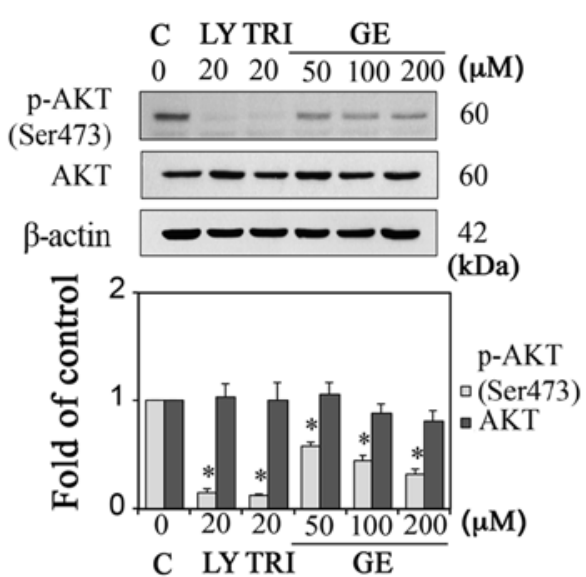

RMCCA-1

$\mathrm{E}$

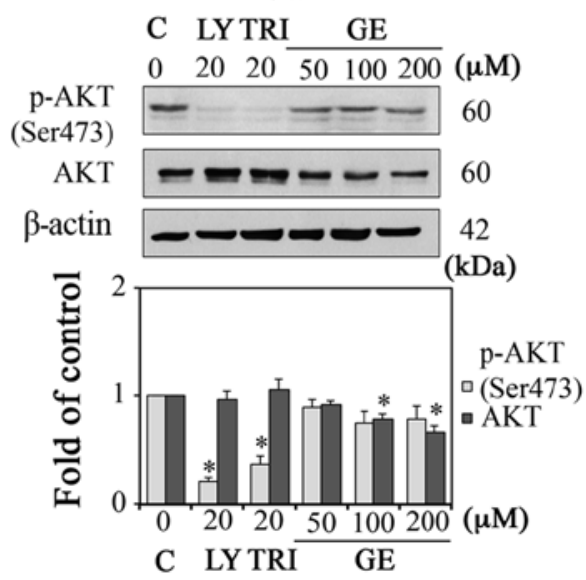

C

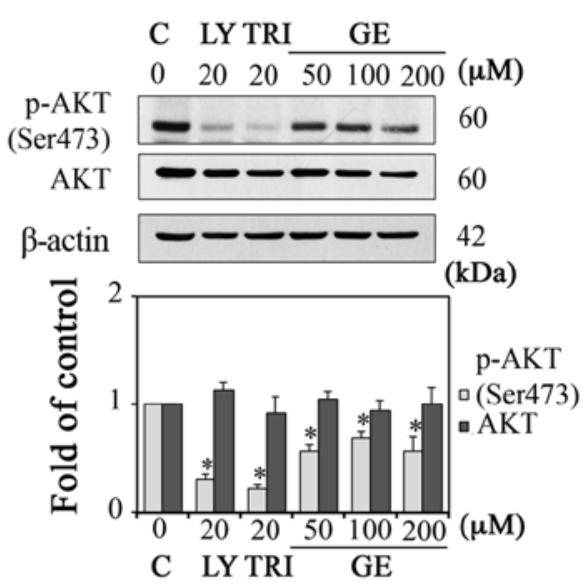

F

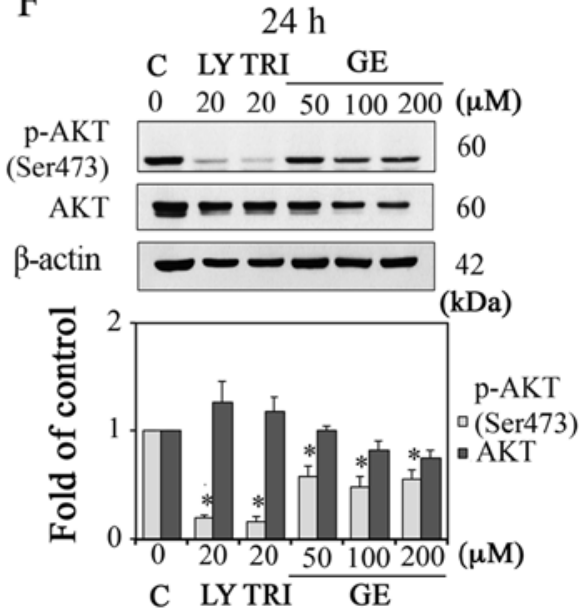

Figure 2. Effect of GE on AKT proteins in HuCCA-1 and RMCCA-1 cells. Western blot analysis and quantification of the expression levels of p-AKT (Ser473) and AKT in cells treated with 10,50, 100 and $200 \mu \mathrm{M} \mathrm{GE,} 20 \mu \mathrm{M} \mathrm{LY}$ and $20 \mu \mathrm{M}$ TRI, in complete medium. Results in HuCCA-1 cells at (A) $0.5 \mathrm{~h}$, (B) $6 \mathrm{~h}$ and (C) $24 \mathrm{~h}$ post-treatment, and RMCCA-1 cells at (D) $0.5 \mathrm{~h},(\mathrm{E}) 6 \mathrm{~h}$ and (F) $24 \mathrm{~h}$ post-treatment. Data are presented as the mean \pm standard error of the mean of at least three independent experiments. "P<0.05, vs. C. GE, genistein; LY, LY294002; TRI, triciribine; C, control (0.1\% DMSO vehicle); p-, phosphorylated.

GE concentrations ranging between 10 and $200 \mu \mathrm{M}$ exhibited a dose- and time-dependent induction of cytotoxic effects in the HuCCA-1 and RMCCA-1 cells. A statistically significant cytotoxic effect $(\mathrm{P}<0.05)$ of $\mathrm{GE}$ was observed, starting at a GE concentration of $50 \mu \mathrm{M}$ in the HuCCA-1 cells (Fig. 1A) and $100 \mu \mathrm{M}$ in the RmCCA-1 cells (Fig. 1B) when treated for $48 \mathrm{~h}$.

GE reduces the protein expression of $p-A K T$ in $H u C C A-1$ and RMCCA-1 cells. AKT protein is a promising target for CCA treatment as its expression and activation increase during the development and progression of CCA (5-7). Studies in colorectal cancer cells have demonstrated that GE can induce apoptosis by inhibiting the activation of AKT (30). Therefore, the present study examined whether GE attenuated the activity of AKT in the CCA cell lines. LY294002 (PI3K inhibitor) and triciribine (AKT inhibitor) were used as positive controls. As shown in Fig. 2A-F, GE downregulated the protein expression of p-AKT (Ser473) in the two cell lines.
GE alters EGFR signaling in HuCCA-1 and RMCCA-1 cells. As AKT is one of the downstream molecules of EGFR, exhibiting prolonged activation in CCA (31), and GE is a known tyrosine kinase inhibitor (32), the present study aimed to determine the effect of GE on the protein expression of p-EGFR (Tyr1173) in the CCA cell lines. As shown in Fig. 3A-F, GE suppressed the protein expression levels of p-EGFR (Tyr1173) in the HuCCA-1 and RMCCA-1 cell lines.

The mitogen-activated protein kinases (MAPKs), both extracellular signal-regulated kinase (ERK)1/2 and p38, are involved in cell proliferation of $\mathrm{KMCH}-1$ malignant cholangiocyte cells (33). Therefore, the present study investigated the effect of GE on ERK1/2 and p38. The results showed that GE decreased the protein expression levels of p-p38 (Thr180/Tyr182) but enhanced the protein levels of p-ERK1/2 in the two CCA cell lines, as shown in Fig. 4A-D.

Activation of AKT in HuCCA-1 cells is mediated by EGFR and other upstream molecules. The previous experiments 
HuCCA-1

A

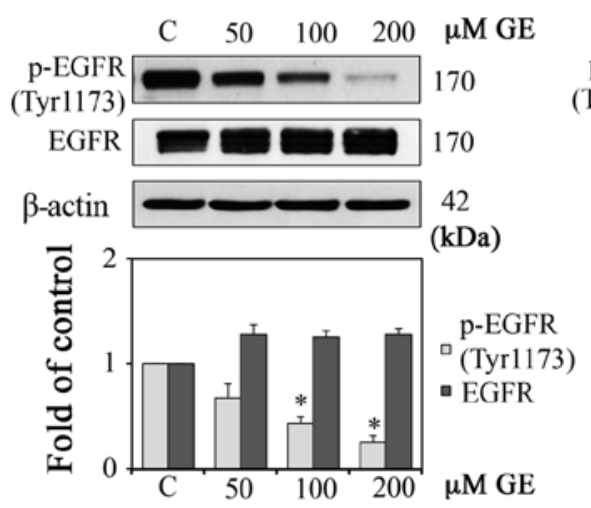

D
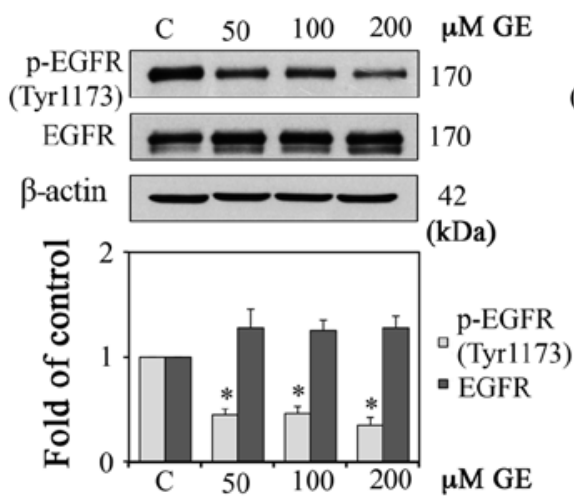

B

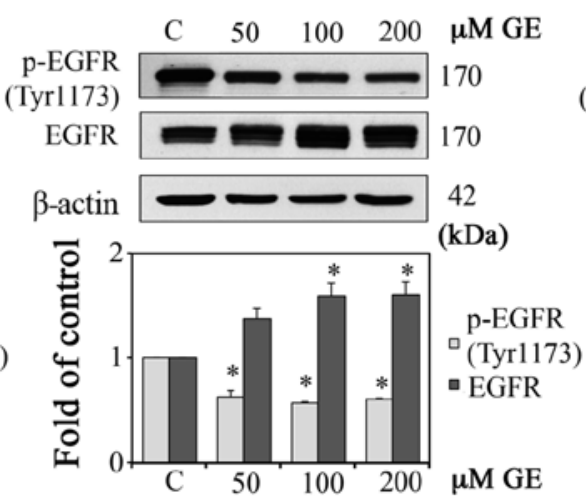

RMCCA-1

E
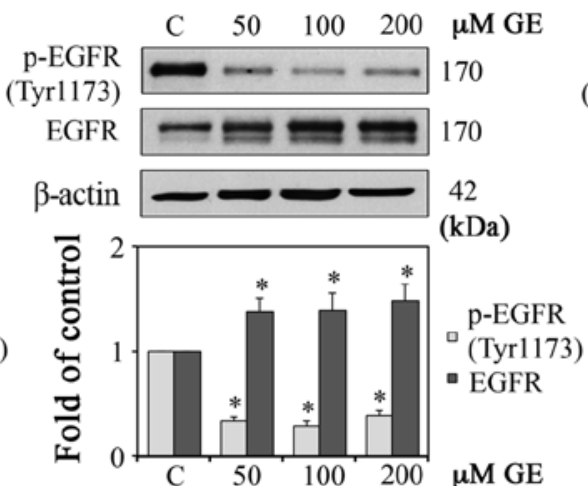

C

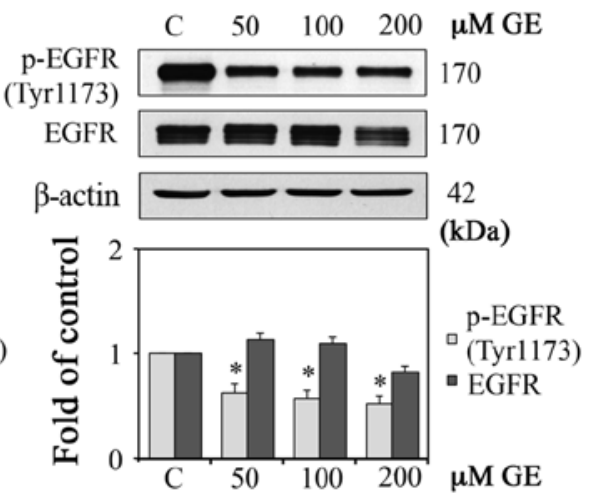

F

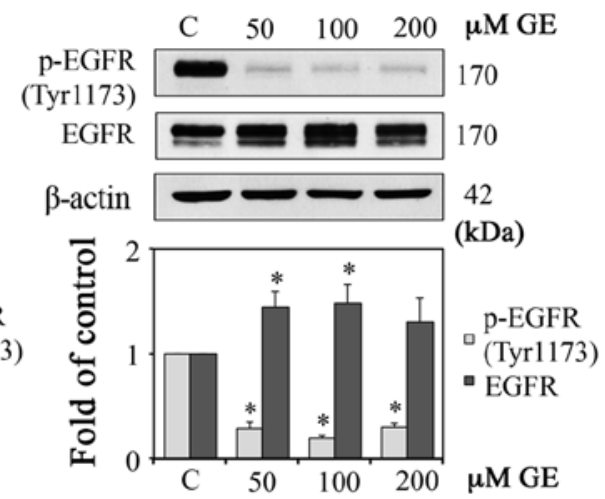

Figure 3. Effect of GE on EGFR proteins in HuCCA-1 and RMCCA-1 cells. Western blot analysis and quantification of the expression levels of p-EGFR (Tyr1173) and EGFR in cells treated with 10, 50, 100 and $200 \mu \mathrm{M} \mathrm{GE}$, in complete medium. Results of HuCCA-1 cells at (A) $0.5 \mathrm{~h}$, (B) $6 \mathrm{~h}$ and (C) $24 \mathrm{~h}$ post-treatment, and (D-F) RMCCA-1 cells at (D) $0.5 \mathrm{~h},(\mathrm{E}) 6 \mathrm{~h}$ and (F) 24 h post-treatment. Data are presented as the mean \pm standard error of the mean of at least three independent experiments. "P<0.05, vs. C. GE, genistein; EGFR, epidermal growth factor receptor; C, control (0.1\% DMSO vehicle); p-, phosphorylated.

demonstrated that GE induced a reduction of active p-EGFR and p-AKT. The activation of AKT can be mediated by upstream molecules other than EGFR. It has been shown that non-genomic ER signaling can crosstalk with EGFR, which leads to the activation of ERK $1 / 2$ and consequently induces cell growth (29). The present study examined whether the activation of AKT in CCA cells is mediated only by EGFR, or involves other molecules, including ER. The preliminary results revealed that HuCCA- 1 cells expressed ER $\alpha$ and ER $\beta$ proteins, whereas RMCCA-1 cells expressed only ER $\beta$ protein. Therefore, only HuCCA-1 cells were utilized in this and the following experiments in order to investigate the role of ER in the effects of GE. To examine whether the GE-inhibited activation of AKT is mediated by EGFR or other molecules, the EGFR inhibitor (AG1478) was utilized as a positive control. As shown in Fig. 5A and B, GE markedly reduced the protein expression levels of p-EGFR (Tyr1173) and p-AKT (Ser473), whereas AG1478 $(10 \mathrm{nM})$ inhibited the protein expression of p-EGFR (Tyr1173) only. These results suggested that, in addition to EGFR, other upstream molecules may be involved in the phosphorylation of AKT in HuCCA-1 cells.
Reduction of total AKT protein and inhibition of the activation of EGFR by GE are enhanced under conditions of E2 deprivation. The two CCA cell lines used in the present study are intrahepatic CCA cell lines. HuCCA-1 cells were originated from $O$. viverrini-infected patients, whereas RMCCA-1 cells were derived from a patient, whose parasitic infection information was not reported $(25,26)$. Therefore, the two cell lines were used in the present study. E2 is involved in CCA cancer proliferation $(10,15)$ and crosstalk exists between ER and EGFR signaling in breast cancer cell lines (29). Therefore, it was hypothesized that E2 may be partly involved in the activation of EGFR in CCA cells. In order to investigate the role of $\mathrm{E} 2$ in the effects of GE, experiments designed in CSS conditions were compared with those in FBS conditions. To confirm whether E2 is involved in the GE-induced activation of EGFR, HUCCA-1 cells were cultured and treated with GE under CSS conditions. As expected, GE markedly suppressed the protein expression level of p-EGFR $(0.61 \pm 0.11-, 0.57 \pm 0.10$ and $0.55 \pm 0.05$-fold of control at GE concentrations of 50, 100, and $200 \mu \mathrm{M}$, respectively) under E2 deprivation (Fig. 6A). However, in FBS conditions (Fig. 3), GE reduced the protein 
A

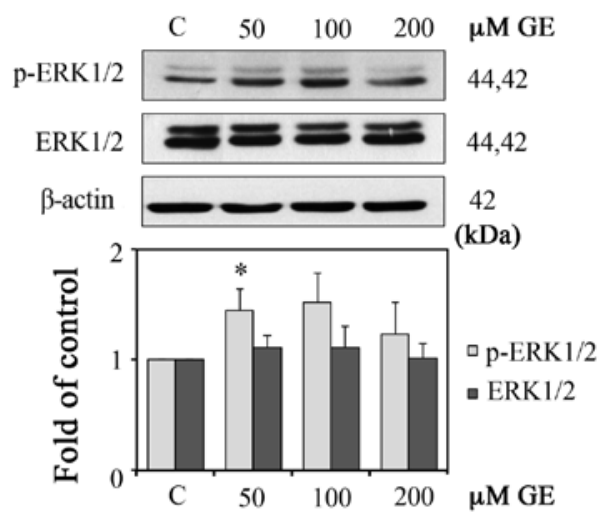

B

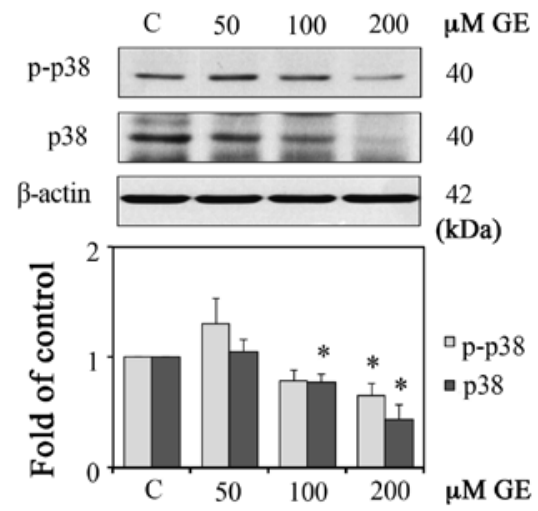

$\mathrm{C}$

$24 \mathrm{~h}$

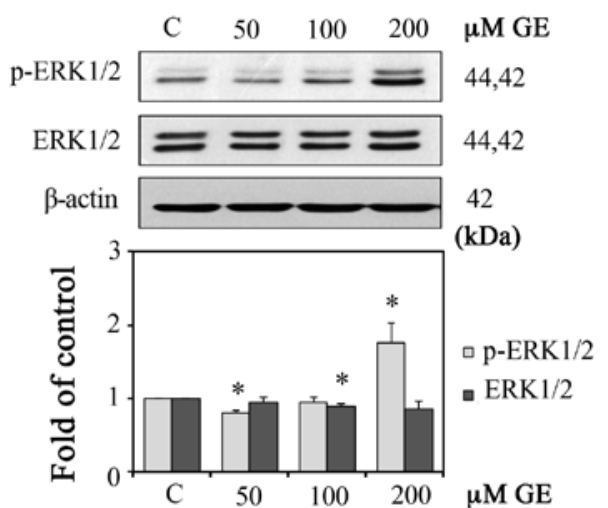

$\mathrm{D}$

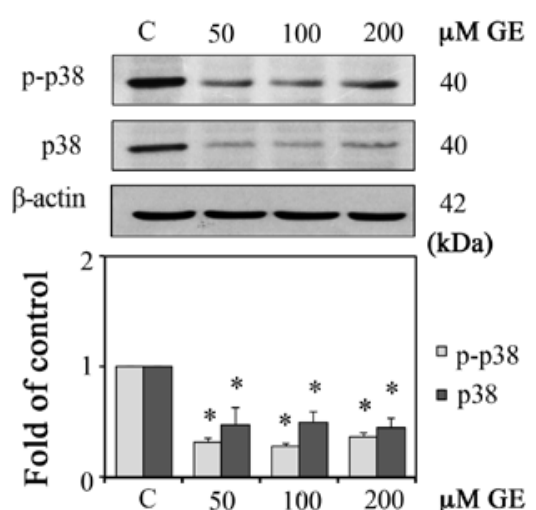

Figure 4. Effect of GE on MAPK proteins in HuCCA-1 and RMCCA-1 cells. Western blot analysis of (A) p-ERK1/2 and ERK, and (B) p-p38 and p38 in HuCCA-1 cells treated with 50, 100 and $200 \mu \mathrm{M}$ GE for $24 \mathrm{~h}$ in complete medium. Western blot analysis of (C) p-ERK1/2 and ERK, and (D) p-p38 and p38 RMCCA-1 cells treated with 50, 100 and $200 \mu \mathrm{M}$ GE for $24 \mathrm{~h}$ in complete medium. Quantification of the western blot data is shown in lower panels. Data are presented as the mean \pm standard error of the mean of at least five independent experiments. "P<0.05, vs. C. GE, genistein; ERK, extracellular signal regulated kinase; $\mathrm{C}$, control (0.1\% DMSO vehicle); p-, phosphorylated.

HuCCA-1

A

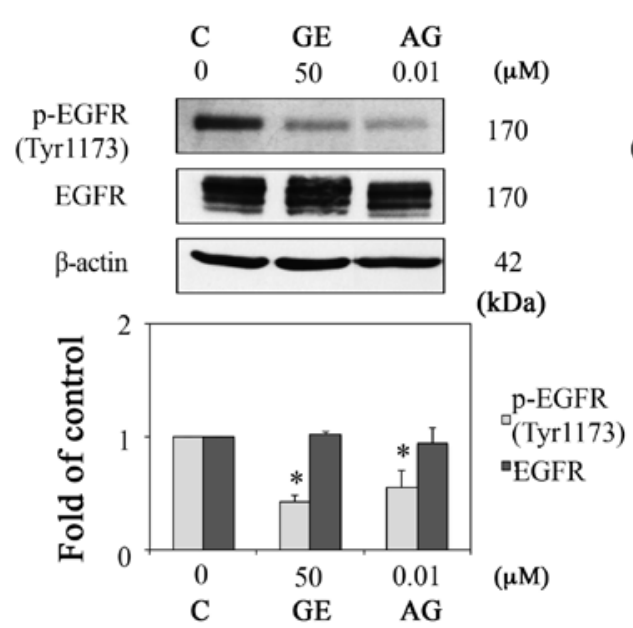

$\mathrm{B}$
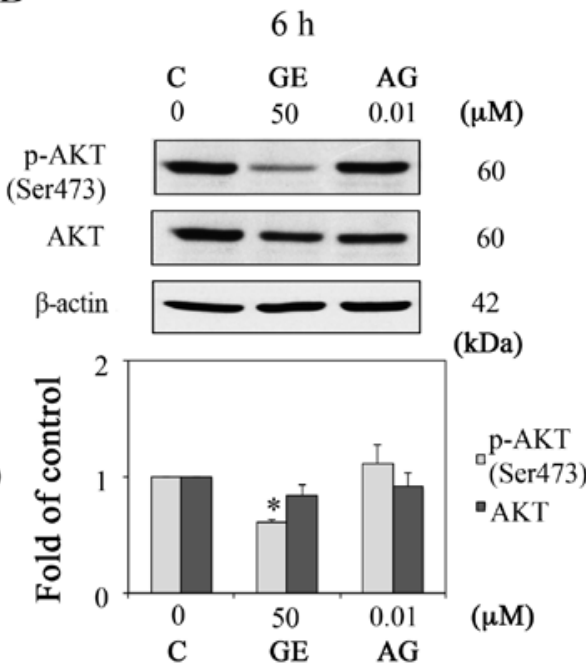

Figure 5. Activation of AKT in HuCCA-1 cells is not only mediated by EGFR. Western blot analysis of (A) p-EGFR (Tyr1173) and EGFR, and (B) p-AKT (Ser473) and AKT, in HuCCA-1 cells treated with 0.1\% DMSO vehicle control, $10 \mathrm{nM}$ AG, and $50 \mu \mathrm{M}$ GE for $6 \mathrm{~h}$ in complete medium (upper panels), and quantification of the western blot data (lower panels). Data are presented as the mean \pm standard error of the mean of at least five independent experiments. ${ }^{*} \mathrm{P}<0.05$, vs. C. GE, genistein; AG, AG1478; C, control; EGFR, epidermal growth factor receptor; p-, phosphorylated. 


\section{HuCCA-1}

A

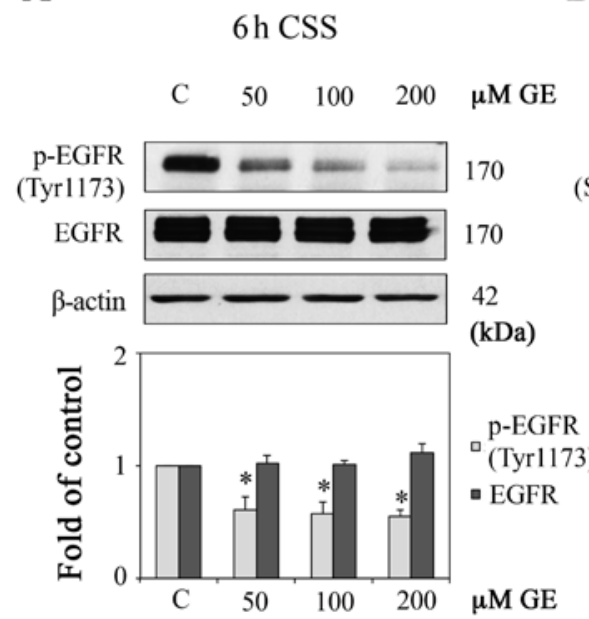

$\mathrm{B}$
$6 \mathrm{~h}$ CSS

$$
\begin{array}{lllll}
\mathrm{C} & 50 & 100 & 200 & \mu \mathrm{M} \mathrm{GE}
\end{array}
$$
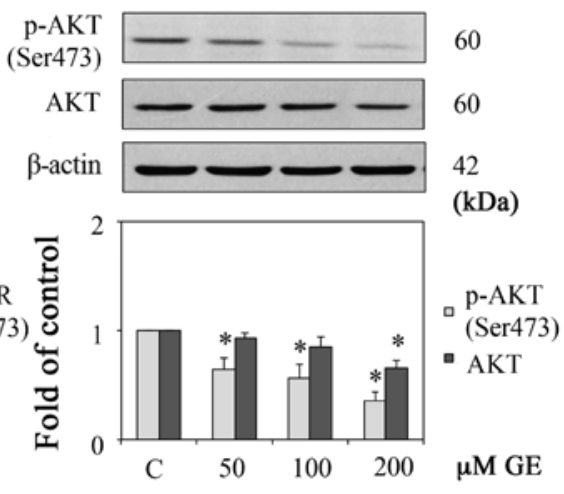

Figure 6. Effect of GE on AKT and EGFR under E2 deprivation. Western blot analysis of (A) p-EGFR (Tyr1173) and EGFR, and (B) p-AKT (Ser473) and AKT, in HuCCA-1 cells treated with 50, 100 and $200 \mu \mathrm{M}$ GE for $6 \mathrm{~h}$ in CSS conditions (upper panels), and quantification of the western blot data (lower panels). In CCS conditions, cells in culture plates were maintained in CCS condition 1 day prior to continual treatment with E2 or GE for $6 \mathrm{~h}$. Data are presented as the mean \pm standard error of the mean of at least five independent experiments. "P<0.05, vs. C. GE, genistein; E2, estrogen; CSS, E2-deprived conditions; $\mathrm{C}, 0.1 \%$ DMSO vehicle control in CSS; EGFR, epidermal growth factor receptor; $\mathrm{p}-$, phosphorylated.

expression levels of p-EGFR to a lesser degree $(0.78 \pm 0.11-$, $0.66 \pm 0.10$ - and $0.64 \pm 0.08$-fold of control for GE concentrations of 50, 100, and $200 \mu \mathrm{M}$, respectively). Additionally, the downregulation of total protein levels of AKT induced by GE under E2-deprivation $(0.93 \pm 0.05-, 0.88 \pm 0.10$ - and $0.66 \pm 0.06$-fold of controls for GE concentrations of 50, 100, and $200 \mu \mathrm{M}$, respectively; Fig. 6B) was higher, compared with the corresponding effect in FBS conditions (1.07 $\pm 0.10-, 0.88 \pm 0.09$ - and $0.81 \pm 0.09$-fold of control for GE concentrations of 50,100, and $200 \mu \mathrm{M}$, respectively; Fig. 2). The inhibitory effects of GE on p-EGFR (Tyr1173) and total AKT were enhanced in the CSS condition, compared with those in the FBS condition. These findings supported the hypothesis that E2 and its receptors may be involved in the activation of EGFR, and may interfere with the reduced phosphorylation of EGFR induced by GE.

GE reduces the production of IL6 and alters the expression of iNOS in HuCCA-l cells. The inflammatory cytokine IL6 is one of the therapeutic targets for CCA (34) and GE has been reported to inhibit the IL6 produced by macrophages (21). Previous experiments have revealed that GE reduces the activation of AKT, which is also a downstream molecule of the IL6 pathway. Therefore, the present study investigated the effect of GE treatment in HuCCA-1 cells on the production of IL6 and the inflammation-associated protein, iNOS. As shown in Fig. 7A, treatment with GE for $6 \mathrm{~h}$ decreased the level of IL6 in a dose-dependent manner in the FBS and CSS conditions. Of note, with the same concentration of GE, treatment in the CSS condition led to a more marked reduction in IL6, compared with that in the FBS condition. The fold changes from the controls in the FBS condition were $0.10 \pm 0.04,0.25 \pm 0.02$ and $0.41 \pm 0.07$, whereas those in the CSS condition were $0.33 \pm 0.04$, $0.54 \pm 0.04$ and $0.66 \pm 0.05$ at GE concentrations of 50,100 and $200 \mu \mathrm{M}$, respectively. In the CSS condition, GE reduced the protein level of iNOS, whereas GE significantly increased the protein level of iNOS in the FBS condition (Fig. 7B).

\section{HuCCA-1}

A

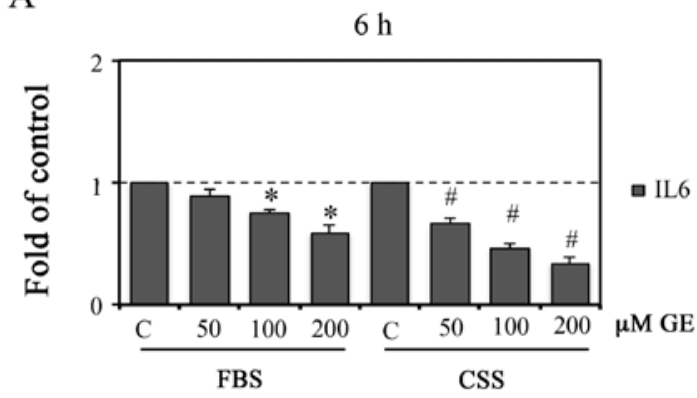

B

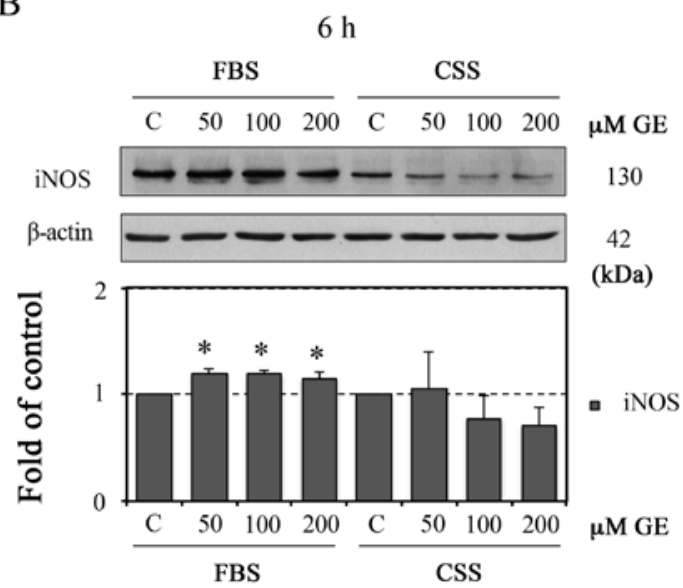

Figure 7. GE reduces induction of IL6 in HuCCA-1 cells. HuCCA-1 cells treated with 50,100 and $200 \mu \mathrm{M}$ GE for $6 \mathrm{~h}$ in FBS or CSS conditions. Following treatment, the cultured media were collected to determine the (A) protein level of IL6 by enzyme-link immunosorbent assay analysis. The level of IL6 ( $\mathrm{pg} / \mathrm{ml})$ was normalized to the total protein of each sample $(\mu \mathrm{g})$. The cell lysates were harvested to evaluate the expression level of (B) iNOS using western blot analysis (upper panel), with quantification of the western blot data (lower panel). Data are presented as the mean \pm standard error of the mean of at least four independent experiments. ${ }^{~} \mathrm{P}<0.05$, vs. $\mathrm{C}$ in FBS; ${ }^{~} \mathrm{P}<0.05$, vs. $\mathrm{C}$ in CSS. GE, genistein; FBS, complete medium; CSS, E2-deprived conditions; C, $0.1 \%$ DMSO vehicle control; IL6, interleukin 6; iNOS, inducible nitric oxide synthase. 
A

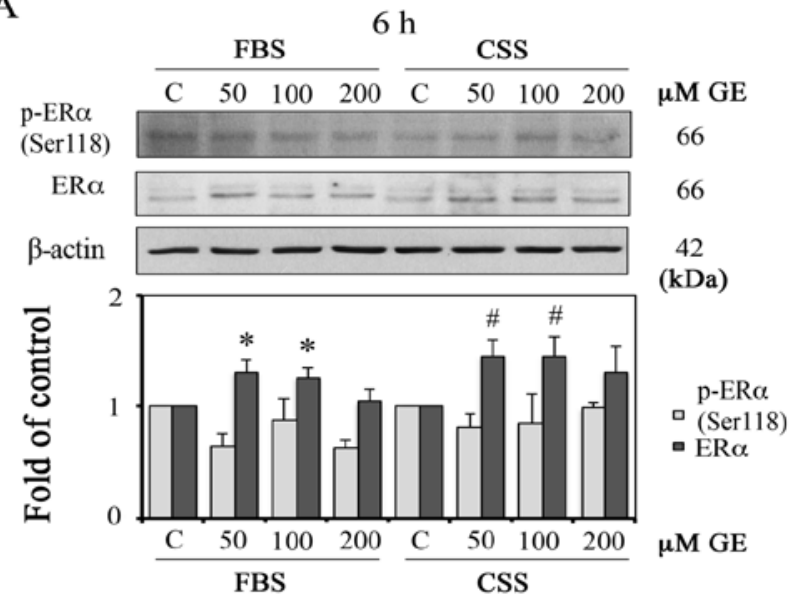

B

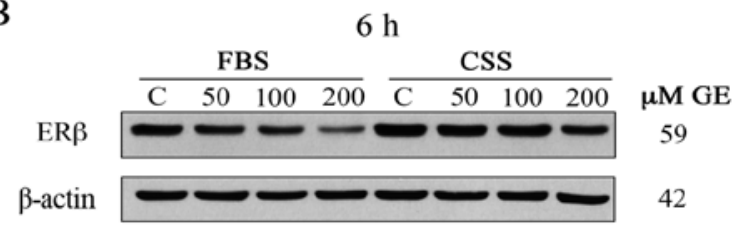

(kDa)

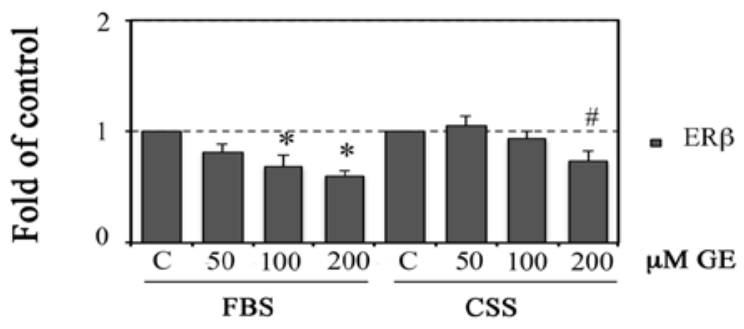

$\mathrm{C}$

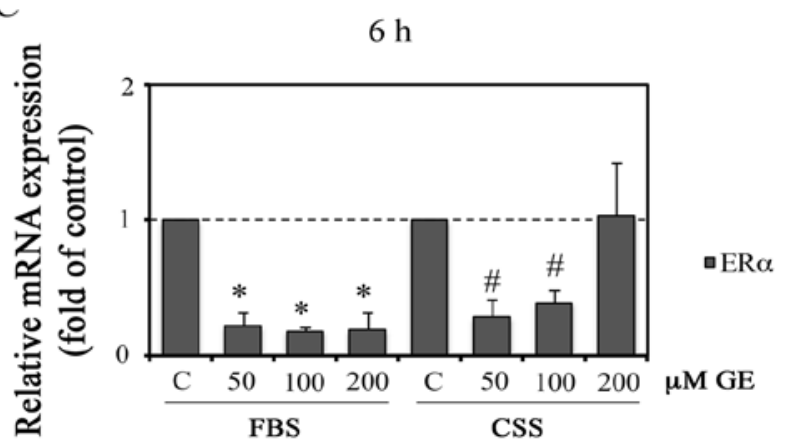

HuCCA-1
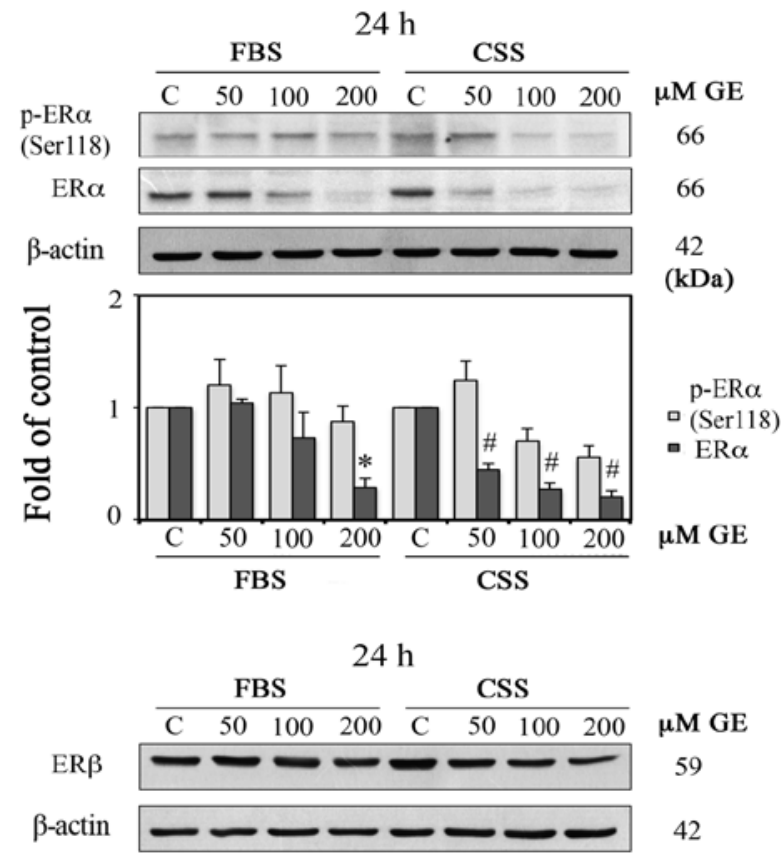

(kDa)

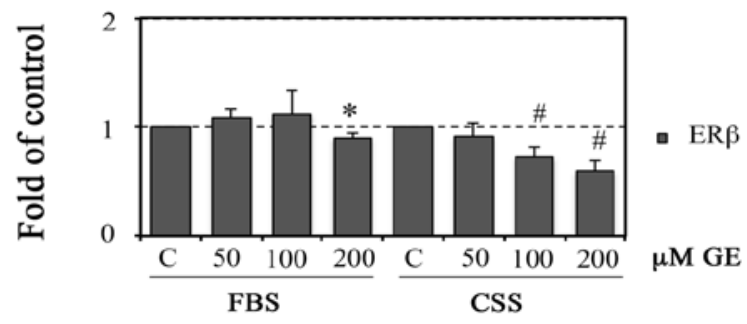

$6 \mathrm{~h}$

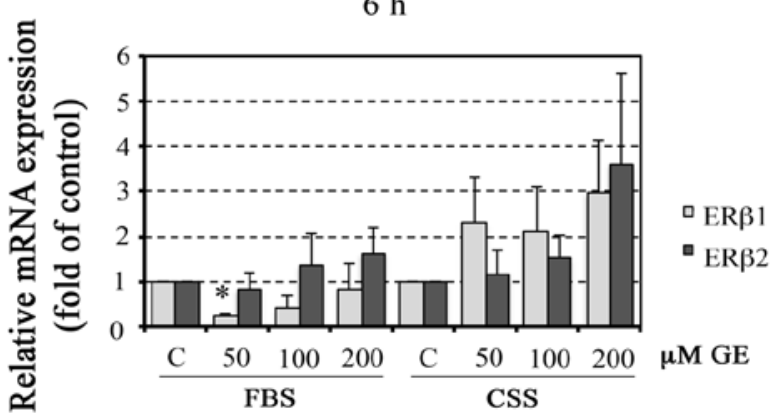

Figure 8. Effect of GE on protein and mRNA expression of ER in HuCCA-1 cells. Western blot analysis of protein expression of (A) p-ER (Ser118) and ER $\alpha$ and (B) ER $\beta$ in HuCCA-1 cells treated with 50, 100 and $200 \mu \mathrm{M} \mathrm{GE}$ for $6 \mathrm{~h}$ (left) and $24 \mathrm{~h}$ (right) in FBS or in CSS (upper panels), with quantification of the western blot data (lower panels). Relative mRNA expression of (C) $E R \alpha$ (left), and of $E R \beta 1$ and $E R \beta 2$ (right) in HUCCA-1 cells treated with or 50, 100 and $200 \mu \mathrm{M}$ GE for $6 \mathrm{~h}$ in FBS or in CSS, analyzed using reverse transcription-quantitative polymerase chain reaction analysis. Data are presented as the mean \pm standard error of the mean of at least three independent experiments. ${ }^{*} \mathrm{P}<0.05$, vs. $\mathrm{C}$ in FBS; ${ }^{*} \mathrm{P}<0.05$, vs. C in CSS. GE, genistein; FBS, complete medium; CSS, E2-deprived conditions; C, 0.1\% DMSO vehicle control in FBS or CSS; ER, estrogen receptor; p-, phosphorylated.

GE alters the protein and gene expression of ER in $\mathrm{HuCCA}-1$ cells. The results of the present study showed that GE effectively downregulated the phosphorylation of EGFR and induction of IL6 in CSS, compared with FBS conditions, suggesting that ER may be involved in those effects. In addition, GE has been reported to reduce the expression of ER in rat prostates (35). Therefore, the present study further investigated the effects of GE treatment on the expression of ER in HuCCA-1 cells. As shown in Fig. 8A, GE dose-dependently downregulated the protein expression of ER $\alpha$ at $24 \mathrm{~h}$ in FBS and CSS conditions. In addition, the results demonstrated that treatment with GE (100 and $200 \mu \mathrm{M})$ for $24 \mathrm{~h}$ in the CSS condition significantly reduced the level of p-ER $\alpha$ (Ser118), whereas GE at a concentration of $50 \mu \mathrm{M}$ increased the level of p-ER $\alpha$ (Ser118). Additionally, the GE-induced downregulation of ER $\beta$ was observed following $6 \mathrm{~h}$ of treatment in the FBS condition and following $24 \mathrm{~h}$ of treatment in CSS condition (Fig. 8B).

To obtain further insight into the effect of GE on ER $\alpha$ and ER $\beta$ in HuCCA-1 cells, RT-qPCR analysis of the mRNA 
expression of $E R \alpha$ and $E R \beta$ (ER/1 and $E R \beta 2)$ was performed. $E R \beta 1$ was selected as $E R \beta 1$ is translated to $\operatorname{ER} \beta$ protein with a MW of $59 \mathrm{kDa}$, corresponding to the ER $\beta$ protein expressed in HuCCA-1 cells. In addition, the mRNA expression of $E R \beta 2$ was investigated as this gene is widely used in investigations of several types of cancer and has been shown to inhibit $\mathrm{ER} \alpha$ (36). The results demonstrated that treatment with GE for $6 \mathrm{~h}$, with the exception of $200 \mu \mathrm{M}$ in CSS conditions, reduced the mRNA levels of $E R \alpha$. However, despite mediating the downregulation of ER $\beta$ at the protein level, GE induced an upregulation in the gene expression levels of $E R \beta 1$ and $E R \beta 2$, particularly in CSS conditions (Fig. 8C).

\section{Discussion}

In the present study, GE concentrations of $10,50,100$ and $200 \mu \mathrm{M}$ were selected for examining its cytotoxicity in CCA cell lines (Fig. 1). Treatment for 24 and $48 \mathrm{~h}$ with GE at 50, 100 and $200 \mu \mathrm{M}$ reduced cell viability $\sim 0-60 \%$ of that of the control. Previous studies have reported that GE (60 $\mu \mathrm{M}, 72 \mathrm{~h})$ caused a 70\% reduction in cell viability in HT-29 cells (20), and GE (50 $\mu \mathrm{M}, 72 \mathrm{~h})$ induced $40 \%$ cell death in MDA-MB231 cells (23). Therefore, the range of GE concentrations used in the present study included non-toxic to cytotoxic concentrations and were in line with concentrations used in previous studies. Based on its effects on CCA cells, GE concentrations of 50-200 $\mu \mathrm{M}$ were selected for further experiments.

The results of the present study suggested that the CCA cells were not particularly sensitive to GE. CCA is known to be resistant to chemotherapy, and this type of cancer has a poor prognosis with a high mortality rate (37). Therefore, identifying novel drugs is required. Despite showing that high concentrations are required to induce cytotoxicity, GE may be of translational value in CCA. In addition, cancer cells exhibit higher sensitivity to the cytotoxic effect of GE than normal cells. In human leukemic HL-60 and MOLT-4 cells, $185 \mu \mathrm{M}$ of GE induced cytotoxicity, whereas no cytotoxic effect was found in normal human lymphocytes (38). In addition, this natural-occurring compound is found in soybean products, which are usually consumed by the Asian population. The daily intake of GE is $49.88 \mu \mathrm{Mol}$ per day (13.48 $\mathrm{mg}$ per day) in the Japanese population and higher in the vegan Asian population (39). Therefore, the GE concentrations of 50 and $100 \mu \mathrm{M}$ used in the present study are possible to achieve in physiological conditions. However, the in vitro concentrations of GE used in the present study require further consideration and conversion prior to utilization in in vivo investigations.

The expression and activation of AKT protein increases during the development and progression of CCA (6). Furthermore, an activated PI3K/AKT signaling pathway is frequently found in CCA cells resistant to chemotherapy (8). The present study investigated the effects of GE in CCA cells. The results demonstrated that GE reduced CCA cell viability and inhibited the phosphorylation of AKT. The resulting data are in agreement with previous reports that showed GE inhibits cell growth in several types of cancer, including HCT-116 and LoVo colorectal cancer cells by reducing the activation of AKT (30), and inhibiting the activation of PI3K/AKT enhances cytotoxicity of oxaliplatin in CCA cell lines (40).
The present study showed that GE significantly inhibited the activity of EGFR, as evidenced by a decrease in active p-EGFR (Tyr1173). Previous reports have shown that EGFR is involved in the proliferation and progression of CCA $(31,41,42)$. It has been shown that GE suppresses the proliferation of proliferative cholangitis in rat models, where the expression of EGFR is high (43). Furthermore, GE conjugated with recombinant human EGF has the capability to inhibit EGFR tyrosine kinase and to trigger rapid apoptotic cell death in EGFRpositive MDA-MB231 and BT-20 breast cancer cells (44). These reports support the results of the present study that GE inhibited the activities of AKT and EGFR, and this was involved in the reduced viability observed in the HuCCA-1 and RMCCA- 1 cells.

It is well established that MAPK signaling can be activated upon the activation of EGFR. ERK1/2 and p38 are members of the MAPK family of cell signaling proteins. The signaling cascades of ERK1/2 and p38 and their upstream components, including ras, Raf, MEK and EGFR are associated with the transformation and progression of several types of cancer (45). A study investigating the KMCH-1 malignant cholangiocyte cell line indicated that mitogens can stimulate cell growth via the activation of ERK1/2 and p38. However, only p38 was involved in the anchorage-independent growth of this cell line (33). The present study revealed that GE inhibited the activation of $\mathrm{p} 38$, as evidenced by the reduction in the protein expression level of p-p38 in HuCCA-1 and RMCCA-1 cells. This finding is in line with a previous report in human prostate cancer cell lines that GE inhibited the activation of p38, leading to the inhibition of cell invasion (46). Therefore, it is possible that GE may also inhibit anchorage-independent transformed cell growth through the inactivation of p38 in CCA. Despite the reduced activation of $\mathrm{p} 38$, the results of the present study demonstrated that GE increased the protein expression levels of p-ERK1/2 in the two CCA cell lines. The activation of ERK1/2 is known to be involved in cell proliferation. However, several studies have demonstrated enhancement in the protein levels of p-ERK1/2 in cells undergoing apoptosis. For example, cisplatin increased the protein levels of p-ERK $1 / 2$ in a dose- and time-dependent manner, which was involved in the induction of apoptosis in $\mathrm{HeLa}$ cells (47). The GE-induced induction of G2/M cell cycle arrest in MDA-MB231 human breast cancer cells was also mediated via the activation of ERK1/2 (48). These reports are in line with the results of the present study, which showed that GE induced the phosphorylation of ERK1/2 in CCA cells. Taken together, the present study suggested that ERK1/2 and p38 were involved in the growth inhibitory effect of GE in CCA cells, but through a different mechanism of action. GE affects the inhibition of cell invasion and induction of cell cycle arrest through MAPK signaling. However, the present study did not focus on the effects of GE on cell cycle machinery. The effects of GE on MAPK signaling in CCA require further investigation.

AKT is the intermediate molecule of various pathways, including EGFR. Upon inhibiting EGFR kinase activity with AG1478, the activity of AKT is reduced, as demonstrated by a reduction in the phosphorylation of AKT in colorectal adenocarcinoma (49), nasopharyngeal carcinoma (50) and breast cancer cells (51). In the present study, although GE treatment 
led to a reduction in the phosphorylation of EGFR and AKT, treatment with AG1478, an EGFR kinase inhibitor, in the HuCCA-1 cells reduced the phosphorylation of EGFR only, and not its downstream molecule AKT. These results suggested that, at least in HuCCA-1 cells, activation of the phosphorylation of AKT is induced not only by EGFR. Human epidermal growth factor receptor 2, another member of the EGFR family, has been shown to be involved in HuCCA-1 cell proliferation and invasion through the AKT pathway (52). In addition to the EGFR family of proteins, the activation of AKT by IL6 has also been reported. It has been shown that the growth of CCA cell lines stimulated by IL6 occurred via an AKT-dependent mechanism (53). Of note, in the present study, the suppression of p-AKT by GE was more prominent following a short $(0.5 \mathrm{~h})$ duration of treatment, compared with a longer (6-24 h) duration of treatment. This may be due to cell compensation for the reduced activity of AKT, which is a crucial molecule in several pathways, particularly those involved in cell survival and chemoresistance in CCA (5-8). Additionally, a previous study suggested that E2 enhances the protein expression levels of p-AKT, p-ERK1/2 and ER $\alpha$, leading to the stimulation of CCA cell proliferation (10).

Previous studies have indicated that there is crosstalk between ER $\alpha$ and EGFR in breast cancer, leading to activation of the downstream molecules of EGFR signaling pathways, including MAPK and AKT pathways $(12,29,31,54,55)$. Additionally, it has been reported that serum levels of E2 in patients with CCA increase in concentrations corresponding to an optimal dose for stimulating the proliferation and invasion of CCA cell lines in vitro (16). Based on the above information, and as GE is also an agonist of ER $\beta$, the present study investigated whether E2 and ER were involved in the inhibitory effect of GE observed in the CCA cell lines. The results showed that the GE-induced inhibition of the activities of AKT and EGFR was enhanced in the absence of E2. This suggested the involvement of E2 in the inhibitory effect of GE and the growth of HuCCA-1 cells. In the presence of E2, GE competes with E2 for ER binding and, as it has a higher affinity towards $E R \beta$, causes a growth inhibitory effect, which is a predominant effect of the activation of $\operatorname{ER} \beta$ (56). In E2 deprivation, GE binds to ER $\beta$, causing increased growth inhibition. However, the growth inhibitory effect of GE may be independent of the ER-mediated pathway. As reported in other cell lines and evidenced in CCA cells in the present study, GE possesses a tyrosine kinase-inhibitory effect. The GE-induced inhibition of the activities of EGFR and AKT may lead to a reduction of CCA cell growth. Therefore, the inhibition of EGFR and AKT evidenced following GE treatment may be mediated via its tyrosine kinase inhibiting effects and/or via interfering with the crosstalk between nongenomic ER and EGFR signaling.

CCA is associated with chronic inflammation of the bile duct (57). Upon binding to its receptor, E2, has been shown to act as an anti-inflammatory and anticarcinogenic by inhibiting the production of IL6 in DEN-induced liver cancer in animal models (58). The cytokine IL6 is important in CCA cell growth. Its signaling involves a complex network of different pathways, including the AKT pathways $(4,59)$ and MAPK (60) pathways. The data presented in the present study showed that GE reduced the production of IL6 in
HuCCA-1 cells. This result is in line with previous reports that GE possesses anti-inflammatory properties (22) and can inhibit the production of IL6 by macrophages stimulated with lipopolysaccharide (21). Additionally, the present study found that the GE-induced decrease in the production of IL6 in CSS conditions was more marked, compared with that in FBS conditions. These results suggested that E2 was involved in the phosphorylation of AKT, and also in the induction of IL6 in HuCCA-1 cells. This finding is in agreement with a previous report that E2 stimulated the production of IL6 in non-malignant biliary epithelial cells and malignant biliary epithelial cells expressing ER $\alpha$ (17). Therefore, in addition to EGFR, the results suggested that E2, ER and IL6 may also be involved in the inhibitory effect of GE and the growth of CCA cells.

Although it has been reported that GE can attenuate the nitric oxide released via iNOS in activated macrophages (61), the results of the present study demonstrated that GE increased the protein expression levels of iNOS in HuCCA-1 cells, despite decreased levels of IL6. However, a report by Nakaya et al demonstrated that GE and E2 upregulated the protein expression and activity of iNOS through ER pathways in RAW246.7 macrophage cells (62). This finding is in accordance with the results of the present study, which showed that GE induced the expression of iNOS in the presence of E2. The discrepancy in these findings may be due to differences in cell type and inflammatory stages. The HuCCA-1 cell line was established from CCA tissue fragments surgically removed from a male patient from Thailand diagnosed with chronic infection due to liver fluke (25).

The results of the present study suggested the involvement of E2 on the growth-inhibiting effects of GE in CCA cells. This suggests that its receptor, ER, is likely to be involved. GE has been identified as an agonist of ER $\beta$; however, this compound can bind $\mathrm{ER} \alpha$ and $\mathrm{ER} \beta$, of which binding affinity to $\operatorname{ER} \beta$ is $20-30$-fold higher than that to $\operatorname{ER} \alpha(63,64)$. The data in the present study showed that, at $24 \mathrm{~h}$, GE (100 and $200 \mu \mathrm{M})$ in CSS conditions reduced the protein expression levels of $\mathrm{p}-\mathrm{ER} \alpha$ (Ser118), ER $\alpha$ and ER $\beta$, whereas the mRNA expression of $E R \alpha$ was downregulated at $6 \mathrm{~h}$. This result is consistent with a previous report that showed that GE downregulated the expression of ER in rat prostates (35). In the present study, although GE reduced the protein expression of $\operatorname{ER} \beta$, there were no significant changes in the mRNA expression levels of $E R \beta 1$ and $E R \beta 2$ in the CSS conditions. These results suggested that the GE-induced reduction in $\mathrm{ER} \beta$ protein was not at the transcriptional level. However, the effects of GE on $p-E R \beta$ were not measured in the present study, as information on the function of $p-E R \beta$ remains limited. As the ER pathway has been shown to be associated with the AKT (12) and IL6 (17) signaling cascades, the downregulation of ER induced by GE observed in the present study may be involved in the GE-induced inhibition of IL6 and $\mathrm{AKT}$ in CCA.

In conclusion, the present study is the first, to the best of our knowledge, to demonstrate that GE can reduce the growth of CCA cell lines via inhibition of the activities of EGFR, AKT and IL6. The mechanism was, in part, associated with downregulation of the protein and mRNA expression levels of ER. The present study provided preliminary results for further 
investigations to generate further translational value for GE in the treatment of CCA, for example, modifying GE structure to improve its activity, using GE to sensitize CCA to conventional treatments, and potentially using GE for chemoprevention as a therapeutic supplement in CCA.

\section{Acknowledgements}

Not applicable.

\section{Funding}

This study was supported in part by a grant (no. EHT-R-4/2556) from The Center of Excellence on Environmental Health and Toxicology, Science and Technology Postgraduate Education and Research Development Office (PERDO), Ministry of Education, Thailand.

\section{Availability of data and materials}

The analyzed datasets generated during the study are available from the corresponding author on reasonable request.

\section{Authors' contributions}

PT performed the experiments, data analysis and drafted the manuscript. AT initiated and monitored the research, supervised the study design, data interpretation and the drafting and revision of manuscript. PW and JS performed data interpretation and also assisted in the drafting of the manuscript. All authors have read and approved the final manuscript.

\section{Ethics approval and consent to participate}

Not applicable.

\section{Consent for publication}

Not applicable.

\section{Competing interests}

The authors declare that they have no competing interests.

\section{References}

1. Songserm N, Promthet S, Wiangnon S and Sithithaworn P Prevalence and co-infection of intestinal parasites among thai rural residents at high-risk of developing cholangiocarcinoma: A cross-sectional study in a prospective cohort study. Asian Pac J Cancer Prev 13: 6175-6179, 2012.

2. Jaiswal M, LaRusso NF, Burgart LJ and Gores GJ: Inflammatory cytokines induce Dells by a nitric oxide-dependent mechanism. Cancer Res 60: 184-190, 2000.

3. Sripa B, Thinkhamrop B, Mairiang E, Laha T, Kaewkes S, Sithithaworn P, Periago MV, Bhudhisawasdi V, Yonglitthipagon P, Mulvenna J, et al: Elevated plasma IL-6 associates with increased risk of advanced fibrosis and cholangiocarcinoma in individuals infected by Opisthorchis viverrini. PLoS Negl Trop Dis 6: e1654, 2012.

4. Kobayashi S, Werneburg NW, Bronk SF, Kaufmann SH and Gores GJ: Interleukin-6 contributes to Mcl-1 up-regulation and TRAIL resistance via an Akt-signaling pathway in cholangiocarcinoma cells. Gastroenterology 128: 2054-2065, 2005.
5. Meng F, Henson R, Lang M, Wehbe H, Maheshwari S, Mendell JT, Jiang J, Schmittgen TD and Patel T: Involvement of human micro-RNA in growth and response to chemotherapy in human cholangiocarcinoma cell lines. Gastroenterology 130: 2113-2129, 2006.

6. Yothaisong S, Thanee M, Namwat N, Yongvanit P, Boonmars T, Puapairoj A and Loilome W: Opisthorchis viverrini infection activates the PI3K/AKT/PTEN and $W n t / \beta$-catenin signaling pathways in a Cholangiocarcinogenesis model. Asian Pac J Cancer Prev 15: 10463-10468, 2014.

7. Ewald F, Nörz D, Grottke A, Hofmann BT, Nashan B and Jücker M: Dual Inhibition of PI3K-AKT-mTOR- and RAF-MEK-ERK-signaling is synergistic in cholangiocarcinoma and reverses acquired resistance to MEK-inhibitors. Invest New Drugs 32: 1144-1154, 2014.

8. Yoon H, Min JK, Lee JW, Kim DG and Hong HJ: Acquisition of chemoresistance in intrahepatic cholangiocarcinoma cells by activation of AKT and extracellular signal-regulated kinase (ERK)1/2. Biochem Biophys Res Commun 405: 333-337, 2011.

9. Kamsa-ard S, Wiangnon S, Suwanrungruang K, Promthet S, Khuntikeo N, Kamsa-ard S and Mahaweerawat S: Trends in liver cancer incidence between 1985 and 2009, Khon Kaen, Thailand: Cholangiocarcinoma. Asian Pac J Cancer Prev 12: 2209-2213, 2011.

10. Alvaro D, Barbaro B, Franchitto A, Onori P, Glaser SS, Alpini G, Francis H, Marucci L, Sterpetti P, Ginanni-Corradini S, et al: Estrogens and insulin-like growth factor 1 modulate neoplastic cell growth in human cholangiocarcinoma. Am J Pathol 169: 877-888, 2006.

11. Shao W and Brown M: Advances in estrogen receptor biology: Prospects for improvements in targeted breast cancer therapy. Breast Cancer Res 6: 39-52, 2004.

12. Guo RX, Wei LH, Tu Z, Sun PM, Wang JL, Zhao D, Li XP and Tang JM: $17 \beta$-estradiol activates PI3K/Akt signaling pathway by estrogen receptor (ER)-dependent and ER-independent mechanisms in endometrial cancer cells. J Steroid Biochem Mol Biol 99: 9-18, 2006.

13. Nicholson RI, McClelland RA, Robertson JF and Gee JM: Involvement of steroid hormone and growth factor cross-talk in endocrine response in breast cancer. Endocr Relat Cancer 6: 373-387, 1999.

14. Osborne CK, Shou J, Massarweh S and Schiff R: Crosstalk between estrogen receptor and growth factor receptor pathways as a cause for endocrine therapy resistance in breast cancer. Clin Cancer Res 11: 865s-870s, 2005.

15. Mancino A, Mancino MG, Glaser SS, Alpini G, Bolognese A, Izzo L, Francis H, Onori P, Franchitto A, Ginanni-Corradini S, et al: Estrogens stimulate the proliferation of human cholangiocarcinoma by inducing the expression and secretion of vascular endothelial growth factor. Dig Liver Dis 41: 156-163, 2009.

16. Hunsawong T, SingsuksawatE, In-chon N, Chawengrattanachot W, Thuwajit C, Sripa B, Paupairoj A, Chau-in S and Thuwajit P: Estrogen is increased in male cholangiocarcinoma patients serum and stimulates invasion in cholangiocarcinoma cell lines in vitro. J Cancer Res Clin Oncol 138: 1311-1320, 2012.

17. Isse K, Specht SM, Lunz JG III, Kang LI, Mizuguchi Y and Demetris AJ: Estrogen stimulates female biliary epithelial cell interleukin-6 expression in mice and humans. Hepatology 51: 869-880, 2010.

18. Sakla MS, Shenouda NS, Ansell PJ, Macdonald RS and Lubahn DB: Genistein affects HER2 protein concentration, activation, and promoter regulation in BT-474 human breast cancer cells. Endocrine 32: 69-78, 2007.

19. Liu D, Yan L, Wang L, Tai W, Wang W and Yang C: Genistein enhances the effect of cisplatin on the inhibition of non-small cell lung cancer A549 cell growth in vitro and in vivo. Oncol Lett 8: 2806-2810, 2014

20. Yu Z, Li W and Liu F: Inhibition of proliferation and induction of apoptosis by genistein in colon cancer HT-29 cells. Cancer Lett 215: 159-166, 2004.

21. Ji G, Zhang Y, Yang Q, Cheng S, Hao J, Zhao X and Jiang Z: Genistein suppresses LPS-induced inflammatory response through inhibiting NF- $\kappa \mathrm{B}$ following AMP kinase activation in RAW 264.7 macrophages. PLoS One 7: e53101, 2012.

22. Verdrengh M, Jonsson IM, Holmdahl R and Tarkowski A: Genistein as an anti-inflammatory agent. Inflamm Res 52: 341-346, 2003.

23. Gong L, Li Y, Nedeljkovic-Kurepa A and Sarkar FH: Inactivation of NF-kappaB by genistein is mediated via Akt signaling pathway in breast cancer cells. Oncogene 22: 4702-4709, 2003. 
24. Gossner G, Choi M, Tan L, Fogoros S, Griffith KA, Kuenker M and Liu JR: Genistein-induced apoptosis and autophagocytosis in ovarian cancer cells. Gynecol Oncol 105: 23-30, 2007.

25. Sirisinha S, Tengchaisri T, Boonpucknavig S, Prempracha N Ratanarapee $\mathrm{S}$ and Pausawasdi A: Establishment and characterization of a cholangiocarcinoma cell line from a Thai patient with intrahepatic bile duct cancer. Asian Pac J Allergy Immunol 9: 153-157, 1991

26. Rattanasinganchan $\mathrm{P}$, Leelawat $\mathrm{K}$, Treepongkaruna SA, Tocharoentanaphol C, Subwongcharoen S, Suthiphongchai T and Tohtong R: Establishment and characterization of a cholangiocarcinoma cell line (RMCCA-1) from a Thai patient. World J Gastroenterol 12: 6500-6506, 2006.

27. Milo GE, Malarkey WB, Powell JE, Blakeslee JR and Yohn DS Effects of steroid hormones in fetal bovine serum on plating ang cloning of human cells in vitro. In Vitro 12: 23-30, 1976.

28. Wilson VS, Bobseine K and Gray LE Jr: Development and characterization of a cell line that stably expresses an estrogenresponsive luciferase reporter for the detection of estrogen receptor agonist and antagonists. Toxicol Sci 81: 69-77, 2004

29. Nakareangrit W, Thiantanawat A, Visitnonthachai D Watcharasit P and Satayavivad J: Sodium arsenite inhibited genomic estrogen signaling but induced $\mathrm{pER} \alpha$ (Ser118) via MAPK pathway in breast cancer cells. Environ Toxicol 31: $1133-1146,2016$

30. Qin J, Teng J, Zhu Z, Chen J and Huang WJ: Genistein induces activation of the mitochondrial apoptosis pathway by inhibiting phosphorylation of Akt in colorectal cancer cells. Pharm Biol 54: 74-79, 2016.

31. Yoon JH, Gwak GY, Lee HS, Bronk SF, Werneburg NW and Gores GJ: Enhanced epidermal growth factor receptor activation in human cholangiocarcinoma cells. J Hepatol 41: 808-814, 2004.

32. Akiyama T, Ishida J, Nakagawa S, Ogawara H, Watanabe S, Itoh N, Shibuya M and Fukami Y: Genistein, a specific inhibitor of tyrosine-specific protein kinases. J Biol Chem 262: 5592-5595, 1987.

33. Tadlock L and Patel T: Involvement of p38 mitogen-activated protein kinase signaling in transformed growth of a cholangiocarcinoma cell line. Hepatology 33: 43-51, 2001.

34. Braconi C, Swenson E, Kogure T, Huang N and Patel T: Targeting the IL-6 dependent phenotype can identify novel therapies for cholangiocarcinoma. PLoS One 5: e15195, 2010.

35. Fritz WA, Wang J, Eltoum IE and Lamartiniere CA: Dietary genistein down-regulates androgen and estrogen receptor expression in the rat prostate. Mol Cell Endocrinol 186: 89-99, 2002.

36. Haldosén LA, Zhao C and Dahlman-Wright K: Estrogen receptor $\beta$ in breast cancer. Mol Cell Endocrinol 382: 665-672, 2014.

37. Razumilava $\mathrm{N}$ and Gores GJ: Cholangiocarcinoma. Lancet 383: 2168-2179, 2014

38. Traganos F, Ardelt B, Halko N, Bruno S and Darzynkiewicz Z: Effects of genistein on the growth and cell cycle progression of normal human lymphocytes and human leukemic MOLT-4 and HL-60 cells. Cancer Res 52: 6200-6208, 1992.

39. Nakamura Y, Tsuji S and Tonogai Y: Determination of the levels of isoflavonoids in soybeans and soy-derived foods and estimation of isoflavonoids in the Japanese daily intake. J AOAC Int 83: 635-650, 2000.

40. Leelawat K, Narong S, Udomchaiprasertkul W, Leelawat S and Tungpradubkul S: Inhibition of PI3K increases oxaliplatin sensitivity in cholangiocarcinoma cells. Cancer Cell Int 9: 3, 2009.

41. Yoshikawa D, Ojima H, Iwasaki M, Hiraoka N, Kosuge T, Kasai S, Hirohashi S and Shibata T: Clinicopathological and prognostic significance of EGFR, VEGF, and HER2 expression in cholangiocarcinoma. Br J Cancer 98: 418-425, 2008.

42. Yoshikawa D, Ojima H, Kokubu A, Ochiya T, Kasai S, Hirohashi S and Shibata T: Vandetanib (ZD6474), an inhibitor of VEGFR and EGFR signalling, as a novel molecular-targeted therapy against cholangiocarcinoma. Br J Cancer 100: 1257-1266, 2009 .

43. Jiang L, Jiang LS, Yan LN, Li FY, Wang W, Cheng NS and Wen TF: Effects of epidermal growth factor receptor inhibitor genistein on proliferative cholangitis in rats. J Surg Res 162 59-67, 2010.

44. Uckun FM, Narla RK, Jun X, Zeren T, Venkatachalam T, Waddick KG, Rostostev A and Myers DE: Cytotoxic activity of epidermal growth factor-genistein against breast cancer cells. Clin Cancer Res 4: 901-912, 1998
45. Roberts PJ and Der CJ: Targeting the Raf-MEK-ERK mitogenactivated protein kinase cascade for the treatment of cancer. Oncogene 26: 3291-3310, 2007.

46. Huang X, Chen S, Xu L, Liu Y, Deb DK, Platanias LC and Bergan RC: Genistein inhibits p38 map kinase activation, matrix metalloproteinase type 2 , and cell invasion in human prostate epithelial cells. Cancer Res 65: 3470-3478, 2005.

47. Wang X, Martindale JL and Holbrook NJ: Requirement for ERK activation in cisplatin-induced apoptosis. J Biol Chem 275: 39435-39443, 2000.

48. Li Z, Li J, Mo B, Hu C, Liu H, Qi H, Wang X and Xu J: Genistein induces $\mathrm{G} 2 / \mathrm{M}$ cell cycle arrest via stable activation of ERK1/2 pathway in MDA-MB-231 breast cancer cells. Cell Biol Toxicol 24: 401-409, 2008

49. Bishnupuri KS, Luo Q, Murmu N, Houchen CW, Anant S and Dieckgraefe BK: Reg IV activates the epidermal growth factor receptor/Akt/AP-1 signaling pathway in colon adenocarcinomas. Gastroenterology 130: 137-149, 2006.

50. Zhu XF, Liu ZC, Xie BF, Li ZM, Feng GK, Yang D and Zeng YX: EGFR tyrosine kinase inhibitor AG1478 inhibits cell proliferation and arrests cell cycle in nasopharyngeal carcinoma cells. Cancer Lett 169: 27-32, 2001.

51. Wei Z, Song X and Shaikh ZA: Cadmium promotes the proliferation of triple-negative breast cancer cells through EGFR-mediated cell cycle regulation. Toxicol Appl Pharmacol 289: 98-108, 2015

52. Treekitkarnmongkol W and Suthiphongchai T: High expression of ErbB2 contributes to cholangiocarcinoma cell invasion and proliferation through AKT/p70S6K. World J Gastroenterol 16: 4047-4054, 2010.

53. Frampton G, Invernizzi P, Bernuzzi F, Pae HY, Quinn M, Horvat D, Galindo C, Huang L, McMillin M, Cooper B, et al: Interleukin-6-driven progranulin expression increases cholangiocarcinoma growth by an Akt-dependent mechanism. Gut 61: 268-277, 2012.

54. Shou J, Massarweh S, Osborne CK, Wakeling AE, Ali S, Weiss H and Schiff R: Mechanisms of tamoxifen resistance: Increased estrogen receptor-HER2/neu cross-talk in ER/HER2-positive breast cancer. J Natl Cancer Inst 96: 926-935, 2004.

55. Levin ER: Bidirectional signaling between the estrogen receptor and the epidermal growth factor receptor. Mol Endocrinol 17: 309-317, 2003.

56. Marzioni M, Torrice A, Saccomanno S, Rychlicki C Agostinelli L, Pierantonelli I, Rhönnstad P, Trozzi L, Apelqvist T, Gentile R, et al: An oestrogen receptor $\beta$-selective agonist exerts anti-neoplastic effects in experimental intrahepatic cholangiocarcinoma. Dig Liver Dis 44: 134-142, 2012.

57. Gores GJ: Cholangiocarcinoma: Current concepts and insights. Hepatology 37: 961-969, 2003.

58. Naugler WE, Sakurai T,Kim S, Maeda S, Kim K, Elsharkawy AM and Karin M: Gender disparity in liver cancer due to sex differences in MyD88-dependent IL-6 production. Science 317: $121-124,2007$.

59. Johnson C, Han Y, Hughart N, McCarra J, Alpini G and Meng F: Interleukin- 6 and its receptor, key players in hepatobiliary inflammation and cancer. Transl Gastrointest Cancer 1: 58-70, 2012.

60. Park J, Tadlock L, Gores GJ and Patel T: Inhibition of interleukin 6-mediated mitogen-activated protein kinase activation attenuates growth of a cholangiocarcinoma cell line. Hepatology 30: $1128-1133,1999$

61. Hämäläinen $M$, Nieminen R, Vuorela $P$, Heinonen $M$ and Moilanen E: Anti-inflammatory effects of flavonoids: Genistein, kaempferol, quercetin, and daidzein inhibit STAT-1 and NF-kappaB activations, whereas flavone, isorhamnetin, naringenin, and pelargonidin inhibit only NF-kappaB activation along with their inhibitory effect on iNOS expression and NO production in activated macrophages. Mediators Inflamm 2007: 45673, 2007.

62. Nakaya M, Tachibana $\mathrm{H}$ and Yamada K: Isoflavone genistein and daidzein up-regulate LPS-induced inducible nitric oxide synthase activity through estrogen receptor pathway in RAW264.7 cells. Biochem Pharmacol 71: 108-114, 2005.

63. Kuiper GG, Lemmen JG, Carlsson B, Corton JC, Safe SH, van der Saag PT, van der Burg B and Gustafsson JA: Interaction of estrogenic chemicals and phytoestrogens with estrogen receptor $\beta$. Endocrinology 139: 4252-4263, 1998.

64. Manas ES, Xu ZB, Unwalla RJ and Somers WS: Understanding the selectivity of genistein for human estrogen receptor- $\beta$ using $\mathrm{X}$-ray crystallography and computational methods. Structure 12 : 2197-2207, 2004 